\title{
Ethno-Medicinal Importance of Some Selected Plants Used For the Treatment of Ruminant Animal Diseases in Ekiti State, Nigeria.
}

\author{
Dr. Olanipekun M. K and Dr. Tedela P. O \\ Ekiti-State University, Ado- Ekiti, Nigeria. Department of Plant Science.
}

\begin{abstract}
A survey of medicinal plants used in the treatments of ruminant animals in the rural areas of EkitiState, Nigeria was conducted. A total number of 52 botanicals belonging to 25 families were identified for the treatment of 20 diseased conditions. The result also shown that some herbs were diseased-specific while others were effective as multipurpose remedies. Consequent upon this, features that enhanced the continuous utilization of these botanicals were identified and strategies that could enhance their sustainability were proposed.
\end{abstract}

\section{Introduction}

Ruminants are important animals that are used in the social and ceremonial life of the rural people than other animal species (FDLPCS, 1992). Ruminant rearing supplements incomes, offers employment opportunities, support agriculture and contribute to the health and nutrition of households especially in the rural communities. They are good source of animal proteins. In Nigeria, for example, Brimkmann and Adu (1977) reported that goat meat was estimated to account for about $20 \%$ of all meat consumed in the country.

Incidentally, management of ruminant is largely in traditional hands in the rural areas where ethnoveterinary practices still play important roles (Kudi and Myint 1999). Farmers are scarcely aware of veterinary and improved management services. In some cases, many of those who were aware of the services cannot afford to pay for them because they are expensive. Anthra (1997) reported that over $85 \%$ of 400 small and marginal farming households sampled in a developing country were found using indigenous knowledge to cure their animals. This according to Kayode et al; (2009) might be attributed to the fact that people believed in the system, which they have used for long and found to be very effective. Also, the same treatment may cure many diseased conditions while the practitioners are readily available.

In Ekiti State Nigeria, ruminant production and productivity is largely in the hands of rural farmers which have developed indigenous method for their management. Among the various indigenous methods is the use of botanicals to manage the health of animals.

Consequent on the above, the aim of this study is to identify and document the medicinal usage of plants used for the management of the health of ruminant animals with a view to determine their abundance, identified the endangered species among them and propose strategies that could enhance their conservation

\section{Materials And Methods}

This study was carried out in the existing three Senatorial Districts of Ekiti State Nigeria. The three Districts are Ekiti North, Ekiti South and Ekiti Central Senatorial Districts. In each district, ten rural communities that were still relatively far from urban influence were selected. In each community, ten respondents were randomly selected and interviewed. The interviewed were conducted with a fairly open framework that allowed for focused, conversational and two-way communication (Omotoyinbo 2008; Olanipekun 2010). Also in each community, group interviews were conducted in order to determine group consensus on the ethno-veterinary plant species. Four groups, each consisting of four or five individuals, were interviewed. Information on plants and other traditional methods used for animal health were documented.

Also information on their preparation and administration were sought. Key informants made up of health, community development, forestry and veterinary officials were interviewed to provide secondary information on the use of medicinal plants in the study area. Voucher specimens of the plant species identified were collected, identified and relevant information on them were documented. The specimens were later treated and deposited at the herbarium of the Department of Plant Science; Ekiti State University Ado-Ekiti, Nigeria.

The relative abundance of the botanicals in each community was determined by the time it would take, from the centre of the community, to physically come across the plant specimens. plant specimens that could be sited between zero minutes to five hours were regarded as abundant; those that would take more than 5 hours to be seen were regarded as scarce. 


\section{Results And Discussion}

Field observation revealed that a total of 52 plant species belonging to 29 families were identified as being used for the treatment of ruminant animals' pests and diseases in the study area (Table 1). Though, various plant parts such as leaves, stems, roots and stem barks were being utilized, but the leaves constituted the bulk of the parts used thus supporting the previous assertion of Kayode et al; (2009) that the leaves formed the major parts of the ethno-botanicals in the state.

Table1.List of identified botanicals used for the treatment of ruminant diseases

\begin{tabular}{|c|c|c|c|c|}
\hline $\mathbf{S} / \mathbf{N}$ & BOTANICAL SPECIES & FAMILY NAME & VERNACULAR NAME & PART(S) USED \\
\hline 1 & Acacia arabica (Linn) & Mimosaceae & Kasia & $\begin{array}{l}\text { Fruit and stem } \\
\text { bark }\end{array}$ \\
\hline \multirow{4}{*}{$\begin{array}{l}2 \\
3\end{array}$} & Adansonia digitata (Linn) & & & \\
\hline & & & & \\
\hline & & Bombaceae & Ose & Leaves \\
\hline & Aframomum meleguata (R. Schun) & Zingiberaceae & Ata-ire & Leaves, seeds \\
\hline 4 & Agerantum conyzoides (Linn) & Asteraceae & Imi-esu & Leaves \\
\hline 5 & Allium cepa (Linn) & Alliaceae & Alubasa-elewe & Leaves \\
\hline 6 & Allium sativum (Linn) & Alliaceae & Ayu & $\begin{array}{l}\text { Seeds and } \\
\text { leaves }\end{array}$ \\
\hline 7 & Alstonia boonei (Linn) & Apocynaceae & Alum & $\begin{array}{l}\text { Leaves and } \\
\text { stem bark }\end{array}$ \\
\hline 8 & Amaranthus spinosus (Linn) & Amaranthaceae & Efo elegun & Leaves \\
\hline 9 & Anacardium occidentale (Linn) & Anacardiaceae & Kasu & $\begin{array}{l}\text { Leaves and } \\
\text { stem }\end{array}$ \\
\hline 10 & Annona senagalensis (Linn) & Annonaceae & Abo & Leaves \\
\hline 11 & Aspilia africana (Pers) & Asteraceae & Yunrinyun & Leaves \\
\hline 12 & Azardiracta indica (AJuss) & Meliaceae & Dongoyaro & Leaves \\
\hline 13 & Bridelia africana (Bth) & Euphorbiaceae & Ira & Stem bark \\
\hline 14 & Calotropis procera (R.Br) & Asclepiadaceae & Bomubomu & Leaves \\
\hline 15 & Capsicum frutescens (Linn) & Solanaceae & Ata wewe & Fruit \\
\hline 16 & Caccia occidentale (Linn) & Caesalpinaceae & Kassia & Leaves \\
\hline 17 & Carica papaya (Linn) & Caricaceae & Ibepe & Seeds \\
\hline 18 & Chromoleana odorata (Linn) & Asteraceae & Akintola & Leaves \\
\hline 19 & Citrus aurantifolia (Christn) & Rutaceae & Osan wewe & Fruit and seeds \\
\hline 20 & Elaeis guinensis acq) & Arecaceae & Ope & Fruit, leaves \\
\hline 21 & Ficus exasperata (Linn) & Moraceae & Eepinpin & Leaves \\
\hline 22 & Ficus thoningn (Linn) & Moraceae & Odan & Leaves \\
\hline 23 & Flugea virosa (Linn) & Euphorbiaceae & Isawewe Ameranbabo & Leaves \\
\hline 24 & Gliricidia sepium (Jacq) & Falaaceae & Agunmaniye & Leaves \\
\hline 25 & Gossypium arboretum (Jacq) & Malvaceae & Owu & Leaves \& seeds \\
\hline 26 & Guiera senegalensis (Linn) & Combretaceae & Gedu & Leaves \\
\hline 27 & Helitricum indicum (Linn) & Boranginaceae & Apari igun & Leaves \& stem \\
\hline 28 & Hymenocardia acida (Linn) & Hymenocardiaceae & Orupa & Leaves \\
\hline 29 & Jatropha gossypifolia (Linn) & Euphorbiaceae & Lapalapa funfun & $\begin{array}{l}\text { Leaves, stem \& } \\
\text { latex }\end{array}$ \\
\hline 30 & Jatropha multifida (Linn) & Euphorbiaceae & Ogege & Leaves \\
\hline 31 & Khaya senegalensis (Deir) & Meliaceae & Oganwo & leaves \\
\hline 32 & Lantana camera (Linn) & Verbenaceae & Ewonadele & Leaves \\
\hline 33 & Momordica charantia (Linn) & Cucurbitaceae & Ejirin wewe & Leaves \\
\hline 34 & Moringa oleifera (Lam) & Rubaceae & Igbale & Leaves \\
\hline 35 & Nicotiana tabacum (Linn) & Solanaceae & Taba & Leaves \\
\hline 36 & Ocimum gratisimum (Linn) & Lamiaceae & Efinrin nla & Leaves \\
\hline 37 & Psidium guajava (Linn) & Myraceae & Gurofa & Leaves/fruits \\
\hline 38 & Rauwolfia occidentale (Afz) & Apocynaceae & Asofeyeje & Leaves \\
\hline 39 & Saccharium officinarium (Jacq) & Poaceae & Ireke & Stem \\
\hline 40 & Sida corymbosa (Linn) & Malvaceae & Iseketu & Leaves \\
\hline 41 & Spondia mombin (Linn) & Asteracea e & Ekikan & Leaves \\
\hline 42 & Solanum nodiflorum (Linn) & Solanaceae & Odu & Leaves \\
\hline 43 & Talinum trangulare acq) & Portulaceae & Gbure & Leaves \\
\hline 44 & Tamarindus indica (Linn) & Fabaceae & Ajagbon & Leaves \\
\hline 45 & Tithonia diversifolia (Linn) & Asteraceae & Odod & Leaves \\
\hline 46 & Tridax procumbens (Linn) & Asteraceae & Igbalode & Leaves \\
\hline 47 & Triumfetta cordifolia (A Rich) & Tiliaceae & Akeri & Leaves \\
\hline 48 & Vernona amygdalina (Del.) & Asteraceae & Ewuro & Leaves \\
\hline 49 & Vitex doniana (Sweet) & Verbenaceae & Oriri & Leaves \\
\hline 50 & Waltheria indica (Linn) & Sterculiaceae & Ewe eje & Leaves \& stem \\
\hline 51 & Zea mays (Linn) & Poaceae & Agbado & Seeds \\
\hline 52 & Zingiber officinale (Rosc) & Zingiberaceae & Ajo & Seeds \\
\hline
\end{tabular}

Table 2 revealed that respondents in the study area were all across various socio-economic strata. Thus, the results revealed that these features were not pre-requisites to the awareness of the respondents to the use of botanicals. All the respondents claimed to have used plant species to treat livestock before the study. 
This observation was similar to the one made by Sondermann et al.; (1993) in the Northern Region of Malawi, where farmers crushed local plants or their parts and mixed them together with drinking water for chickens to prevent or cure Newcastle diseases and diarrhea. It was also observed that unlike in human medicines, farmers in the study area did not establish themselves as traditional veterinary healers or practitioners. The use of plant species was used as remedies at subsistence level.

Table 2. Socio-economic characteristics of the respondents of Ekiti State, Nigeria

\begin{tabular}{|c|c|c|c|c|c|}
\hline \multirow[t]{2}{*}{ FEATURES } & \multirow[t]{2}{*}{ DESCRIPTION } & \multicolumn{4}{|c|}{ PROPORTION (\%) RESPONDETNS } \\
\hline & & $\begin{array}{l}E N \\
(n=100)\end{array}$ & $\begin{array}{l}\mathrm{EC} \\
(n=100)\end{array}$ & $\begin{array}{l}\mathrm{ES} \\
(\mathrm{n}=100)\end{array}$ & $\begin{array}{l}\text { AVERAGE } \\
\text { TOTAL (\%) }\end{array}$ \\
\hline \multirow[t]{2}{*}{ Sex } & Male & 20 & 32 & 25 & $25.7 \%$ \\
\hline & Female & 80 & 68 & 75 & $74.3 \%$ \\
\hline \multirow[t]{3}{*}{ Age (Years) } & 10 & - & - & - & - \\
\hline & $10-50$ & 40 & 45 & 40 & $41.7 \%$ \\
\hline & 50 and above & 60 & 55 & 60 & $58.3 \%$ \\
\hline \multirow[t]{2}{*}{ Literacy } & Illiterate & 40 & 80 & 50 & $56.6 \%$ \\
\hline & Literate & 60 & 20 & 50 & $43.3 \%$ \\
\hline \multirow[t]{3}{*}{ Economic Status } & High & 10 & 05 & 15 & $10 \%$ \\
\hline & Medium & 35 & 35 & 30 & $33.3 \%$ \\
\hline & Low & 55 & 60 & 55 & $56.6 \%$ \\
\hline
\end{tabular}

$\mathrm{N}$ is the number of respondents interviewed.

Table 3 Revealed that most of the respondents possessed adequate indigenous knowledge on the botanicals and have experienced them before the study. They were of the opinion that the botanicals were readily available, cheap and economical, easy to apply, highly effective, less toxic and have no side effect.

Table 3. Perception of respondents on ethno-veterinary botanicals in Ekiti State, Nigeria

$\begin{array}{lll}\text { S/N } & \text { DESCRIPTION } & \text { E } \\ 1 & \text { Locally and easily available } & 90 \\ 2 & \text { Cheap and Economical } & 80 \\ 3 & \text { Easy to apply } & 90 \\ 4 & \text { Highly effective } & 90 \\ 5 & \text { No side effects } & 70 \\ 6 & \text { Less toxic } & 80 \\ 7 & \text { Helps where modern veterinary assistant is } & 80 \\ & \text { race or not available } & \\ 8 & \text { Treatment at farmers resistance is possible } & 70 \\ 9 & \text { The process in natural } & 70 \\ 10 & \text { It satisfies the animal owners }\end{array}$

\begin{tabular}{llll}
\multicolumn{3}{l}{ PROPORTION (\%) } & \multicolumn{3}{l}{ OF RESPONDENTS } \\
EN & EC & ES & AVERAGE TOTAL \\
90 & 80 & 80 & 83.3 \\
80 & 70 & 90 & 80.0 \\
90 & 80 & 68 & 79.3 \\
90 & 80 & 64 & 78.0 \\
70 & 70 & 90 & 76.7 \\
80 & 60 & 70 & 70.0 \\
80 & 70 & 60 & 70.0 \\
70 & 70 & 60 & 66.6 \\
70 & 70 & 60 & 66.6 \\
70 & 80 & 80 & 76.2
\end{tabular}

Table 4 revealed the 20 disease conditions identified by the respondents in the study area. Of the 20 disease conditions, diarrhea and cough were most prevalent, thus confirm the previous assertion of Oboegbulem and Chah (1997) that diarrhea, cough and nasal discharges have been the major problems of ruminants in Southern parts of Nigeria. Other diseases conditions identified were worms, helminthes, dystocia, retain placenta, mastitis, botulism, conjunctivitis, trypanosomiasis and body swellings. However, mange, scabies, fleas and ticks were the pests identified in the study area.

Table 4. Ruminants Pests and diseases and their symptoms as identified by respondents in Ekiti-State, Nigeria.

\begin{tabular}{|c|c|c|c|}
\hline $\begin{array}{l}\text { PEST/ } \\
\text { DISEASE }\end{array}$ & $\begin{array}{l}\text { ENGLISH/ } \\
\text { SCIENTIFIC NAME }\end{array}$ & $\begin{array}{l}\text { VERNACULAR } \\
\text { NAME }\end{array}$ & $\begin{array}{l}\text { SYMPTOMS/SIGNS } \\
\text { ORLESSIONS }\end{array}$ \\
\hline \multirow[t]{2}{*}{ (a) Pests } & Lice, fleas and ticks & Eyoo/kokoro & $\begin{array}{l}\text { - small insects that are transmitted } \\
\text { by body contact, whose life-cycle is } \\
\text { completed in relative short time. } \\
\text { - It causes restlessness, dullness and } \\
\text { weakness. } \\
\text { - Often results in sores on the } \\
\text { animals that may serve as entry } \\
\text { points for microbes and finally } \\
\text { caused death. }\end{array}$ \\
\hline & Worms/Helminthes & Araninu & $\begin{array}{l}\text { - worms present in the stool } \\
\text { - Animals lack appetite } \\
\text { - Emaciation and general body } \\
\text { weakness. }\end{array}$ \\
\hline
\end{tabular}


Mange/scabies

(b)
Nutritiona
Diseases

(c) Microbial Diseases

(d)

Environmenta

Diseases
1. Bloat

2. Fever, Dizziness, Anemia

3. Trypanosomiasis

1. Lameness

2. Diarrhea

3. Respiratory Disease

4. Cough/Rinder pest Disease

5. Botulism

6. Veneral Disease

7. Conjunctives

1. Wound/Snake bite
Ekiku

Inu wiwu

Iba, oyi, oji, eje gbigbe

Unsteadiness, rubbing body on

concrete or hard surfaces.

- Bruises on the skin

- Falling of hair

- Leaving scaly and a red skin

-Emaciation, weakness and

depression

of the body.

- Distention of abdomen

- Off feeding, no ruminant

- Labored breathing

- Weakness of the body

- Yellowish urine

- Yellowish of mucus membrane of eye, lips etc.

- Lack of appetite

- Emaciation, pale look

- Inadequate blood

Ounje aipeye - - Staring hair coat

- Unsteadiness, not convenient

- Depression and darkening of the hair coat

- Weakness of the body.

Riro/rolaparolese - Paralysis of animal(s)

- Loss of body weight

- Wound on the cleft and foot

- Difficulties in the breathing

- Depression of the animal(s)

- Persistence watering stooling

Igbe-gburu/Inu - Depression, weakness \& leaning wiwo of animals

- Bloody dropping

- Nasal discharge.

- Discharge of watery substances

from nose

Eemi-lile/ - Swollen of animal(s) face

Ikoawugbe - Sneezing and coughing.

- Severe diarrhea

Iko/Awuku

- Mouth, nose and eye discharges raised hair coat and swollen head, cough and swollen faces

- Lesion of the lower lips

- Twisting of the neck, because of poisoning of food

Orun lilo

Egbo/Oyun oju ara

Aran oju/

oju to nsepin

- Blisters of the vulva

Egbo/gige je ejo

- Stuffy eye.

- Swellings around the neck or root

- Wound noticed on bite side or broken skin

- Swelling of the head

- Pam on the thigh or joints

- Limping of the animal.

- Prolong labor at

parturition

- Retained foetus

- Animal unable to give birth without help.

- Pains on the breast

Egbo Etitu/

- Accumulation of pu

- Area becomes swollen and

painful

- Animals unable to work.

Olobi ti ko le da - Placenta delay to drop explore or drop

- Pains all over the animal's

body. 
Table 5 revealed that various plants were used in different herbal preparations administered to animals. Some plants were used as single remedies while some provided multiple remedies, preventing or curing several kinds of ailments. This observation confirmed the previous assertions of Agharkar (1995) and Anjara (1996) that the juice of leaves or roots of botanicals, such as A.rabica, A,spinosus and C.odorata were used to treat wounds. Also, Dean (1996) reported that villagers in the Pare Mountains of Tanzania used the leaves extract of Solanum spp and C.odorata in treating wounds in ruminant animals.

Similarly, Burkil (1995); Odebiyi and Sofowora (1998) reported that the leaves of F.thonigii and S.mombin leaves aids placenta expulsion in ruminants animals (e.g goats) in South Eastern part of Nigeria.

Table 5. Method of preparations of plant species used for the

Treatment/management of ruminant pests and diseases.

\begin{tabular}{|c|c|c|c|}
\hline PEST/DISEASES & PLANT USED & PART(S) USED & METHODS OF PREPARATION \\
\hline Fleas & $\begin{array}{l}\text { 1. Vernonia } \\
\text { cornifera } \\
\text { 2. Palm Oil }\end{array}$ & $\begin{array}{l}\text { Leaves } \\
\text { Fruits }\end{array}$ & $\begin{array}{l}\text { Squeeze in water and bath the animal } \\
\text { Apply all over the body }\end{array}$ \\
\hline Ticks & $\begin{array}{l}\text { Hand picking } \\
\text { Ficus exasperata }\end{array}$ & & $\begin{array}{l}\text { Pick ticks from the body } \\
\text { Fresh leaves put in the house of the animal } \\
\text { as beddings }\end{array}$ \\
\hline Mites & Palm Oil & & Apply all over the body \\
\hline Mange/scabies & $\begin{array}{l}\text { 1. Palm oil/salt } \\
\text { 2. Engine oil } \\
\text { 3. Sulphur cake } \\
\text { 4. Palm oil } \\
\text { 5. Dregs of palm } \\
\text { oil processing } \\
\text { 6. Palm oil/gun } \\
\text { powder } \\
\text { 7. Kerosine } \\
\text { 8. Gammaline } \\
\text { 9. Hot oil/ } \\
\text { limestone } \\
\text { 10. Used motor oil }\end{array}$ & & $\begin{array}{l}\text { Apply on affected area } \\
\text { Apply on affected area } \\
\text { Grind and dust on the animal } \\
\text { Apply oil on the affected part } \\
\text { Apply dregs on the affected part } \\
\text { Apply mixture on the affected part } \\
\text { Apply on the affected area } \\
\text { Apply on the affected area } \\
\text { Apply on the affected area } \\
\text { Apply on the affected area }\end{array}$ \\
\hline $\begin{array}{l}\text { Disease } \\
\text { Wounds }\end{array}$ & $\begin{array}{l}\text { A. arabica, } \\
\text { A. spinosus, } \\
\text { C. odorata, } \\
\text { M. oleifera }\end{array}$ & & $\begin{array}{l}\text { Pound and extract with water use it to dress } \\
\text { the wound }\end{array}$ \\
\hline Diarrhea & $\begin{array}{l}\text { 1. Vernonia } \\
\text { amygdalina } \\
\text { 2. Adansonia } \\
\text { digitata } \\
\text { 3. M. charantia } \\
\text { 4. Zea mays }\end{array}$ & $\begin{array}{l}\text { Leaves } \\
\text { Leaves } \\
\text { Leaves } \\
\text { Grains }\end{array}$ & $\begin{array}{l}\text { Squeeze in water and use he water to } \\
\text { drench the animal } \\
\text { Squeeze in water and use the water to } \\
\text { drench the animal } \\
\text { Roast and feed the animal }\end{array}$ \\
\hline $\begin{array}{l}\text { Retained placenta } \\
\text { and parturition }\end{array}$ & $\begin{array}{l}\text { 1. F. thoningii } \\
\text { 2. F. virosa } \\
\text { 3. H. indicum } \\
\text { 4. H. acida } \\
\text { 5. S. mombin }\end{array}$ & $\begin{array}{l}\text { Leaves } \\
\text { Leaves } \\
\text { Leaves } \\
\text { Leaves } \\
\text { Leaves }\end{array}$ & $\begin{array}{l}\text { Fresh leaves given the animal } \\
\text { Fresh leaves given the animal } \\
\text { Fresh leaves given the animal } \\
\text { Fresh leaves given the animal } \\
\text { Fresh leaves given the animal }\end{array}$ \\
\hline Mastitis & 1. S. mombin & Leaves & $\begin{array}{l}\text { Drench and also use the leaves to massage } \\
\text { the udder }\end{array}$ \\
\hline $\begin{array}{l}\text { Chronic respiratorsy } \\
\text { disease }\end{array}$ & $\begin{array}{l}\text { 1. A. digitata } \\
\text { 2. A. sativum } \\
\text { 3. A. cepa } \\
\text { 4. A. spinosus } \\
\text { 5. A. indica } \\
\text { 6. C. odorata } \\
\text { 7. C. aurantifolia } \\
\text { 8. E. guineisis } \\
\text { 9. V. doniana } \\
\text { 10. V. paradosa } \\
\text { Palm oil }\end{array}$ & $\begin{array}{l}\text { Leaves } \\
\text { Bulb } \\
\text { Bulb } \\
\text { Leaves } \\
\text { Leaves \& seeds } \\
\text { Leaves } \\
\text { Leaves \& fruits } \\
\text { Fruits } \\
\text { Leaves } \\
\text { Leaves }\end{array}$ & $\begin{array}{l}\text { Macerate in the water and drench } \\
\text { Macerate in the water and drench } \\
\text { Macerate in the water and drench } \\
\text { Macerate in the water and drench } \\
\text { Macerate in the water and drench } \\
\text { Macerate in the water and drench } \\
\text { Macerate in the water and drench } \\
\text { Macerate in the water and drench } \\
\text { Macerate in the water and drench } \\
\text { Macerate in the water and drench } \\
\text { Apply on the affected area. }\end{array}$ \\
\hline $\begin{array}{l}\text { Strong abdominal } \\
\text { pain/constipation }\end{array}$ & $\begin{array}{l}\text { 1. Aspilia } \\
\text { africana } \\
\text { 2. Ocimum } \\
\text { gratisimum } \\
\text { 3. Z. officinarium } \\
\text { 4. E. guinensis } \\
\text { 1. C. papaya }\end{array}$ & & $\begin{array}{l}\text { Leaves extract in water } \\
\text { Leaves extract in water } \\
\text { Macerate in water and drench } \\
\text { Oil palm given the animal. } \\
\text { Ground seeds given the animal }\end{array}$ \\
\hline
\end{tabular}




$\begin{array}{ll} & \text { 2. G. sepium } \\ \text { 3. V. doniana } \\ \text { Mouth ulcer } & \text { 1. A. spinosus } \\ & \text { 2. C. frutescens } \\ \text { 3. J. gossypifolia }\end{array}$

\author{
fresh leaves given the animal \\ Stem bark and fresh leaves given in water. \\ Leaves extract apply on the wound \\ Ground seeds apply on the wound \\ Extract from the leaves and stem apply in \\ the feed.
}

Table 6 revealed the relative abundance of the species identified in the study area. It was observed that 22 of the botanicals could be described as being abundant. The abundant species were mostly species that were cultivated in the study area for other purposes than medicine.

\begin{tabular}{|c|c|c|}
\hline $\begin{array}{l}\mathbf{S} / \\
\mathbf{N} \\
\end{array}$ & BOTANICAL NAME & $\begin{array}{l}\text { MAJOR PRODUCTS OBTAINABLE FROM } \\
\text { CULTIVATION }\end{array}$ \\
\hline 1 & Aframomum meleguata & Seeds as medicine \\
\hline 2 & Agerantum conyzoides & Medicine \\
\hline 3 & Amaranthus spinosus & Medicine \\
\hline 4 & Anacardium occidentale & Fruits and medicine \\
\hline 5 & Aspilia Africana & Animal fodder and ornamental \\
\hline 6 & Azardicacta indica & Erosion and wind control and medicine \\
\hline 7 & Calotropis procera & Ornamental and food preparation \\
\hline 8 & Capsicum frutescens & Fruits and medicine \\
\hline 9 & Caccia occidentale & Shade, stake for yam and erosion control \\
\hline 10 & Carica papaya & Whole plant as wind control \\
\hline 11 & Chromolaena odorata & Medicine from leaves and stem \\
\hline 12 & Citru aurantifolia & Wind breaker, fruits as medicine \\
\hline 13 & Elaeis guinensis & Fruits, wind erosion control \\
\hline 14 & Ficus thoningii & Shade and erosion control \\
\hline 15 & Gliricida sepium & Yam stakes and wind breaker \\
\hline 16 & Momordica charantia & Medicine from leaves and stem \\
\hline 17 & Ocimum gratisimum & Leafy vegetable and medicine \\
\hline 18 & Talinum trangulare & Leafy vegetable and medicine \\
\hline 19 & Tithonia diversoifolia & Ornamental \\
\hline 20 & Tridax procumbens & Folder and medicine \\
\hline 21 & Venona amygdalina & Leafy vegetable and medicine \\
\hline 22 & Zea mays & Fruits as food and medicine \\
\hline
\end{tabular}

In conclusion, in spite of wide network of modern veterinary services, people in the remote areas still consider it inferior to the use of plant species for the treatment of livestock diseases. This is because the botanicals had no side effect; they are locally available and easily accessible. Hence the conservation of these ethnoveterinary botanicals is highly imperative and can be achieved thus:

1. There should be policies aimed at educating farmers on the value of indigenous knowledge

2. Extension agents should work hand in hand with veterinarians on the possibility to blend both the orthodox drugs with the traditional treatments which go a long way to improve animal health care in rural areas

\title{
References
}

[1]. Agbarka, S.P. (1953) Medicinal plants of Bombay Presidency (Scientific Publishers. Jodhpur, India)

[2]. Anjaria J. (1996) Ethnoveterinary Pharmacology in India: past present and future. Pp.137-147. In: C.M. Mc Corkle E. Martias and T.V. Schillhorn Van Veen (Eds). Ethnoveterinary Research and Development. Intermediate Technology Publications, London, U.K. 137-147

[3]. Anthra, (1997). Community-based research on local knowledge systems. The ANTHRA project on ethnoveterinary research. Pp. 13-18 In: Ethnoveterinary Medicine Alternatives for Livestock Development. Proceedings of an International conference held in Pune, India on 4-6 November, 1997. Vol. 1: selected paper, Evelyn Mathias, Rangnekar, D.V and constance M.McCorkle(editors). BAIF Development Research Foundation, Pune India

[4]. Brimkamnn, W.L and Adu, I.F (1977). The problem of goat production in savannah region of Nigeria, National Animal Production Research Institutes, Ahamadu Bello University, Zaria, Nigeria.

[5]. Burkill,I.H.(1995).The useful plants of West TropicalAfrica

[6]. Vol 1Families A-D.Royal Botanical Gardens Pp696.

[7]. Dean, A.R (1996) Traditional and re-applied veterinary in East Africa. Pp. 256-264. In: C.M. Mc Corkel, E. Mathias and T.W. Schillhorn VanVeen (Eds). Ethnoveterinary Research and Development. Intermediate Technology Publications London.

[8]. 7. FDLPCS, (1992) Nigeria Livestock Resources Volume 2. National Synthesis. Federal Department of Livestock and Pest Control Services, Abuja, Nigeria.

[9]. Kayode, J; Olanipekun M.k. and Tedela P.O. (2009) Medicobotanical Studies in relation to veterinary medicine in Ekiti-State, Nigeria: Checlist of botanicals used in treating poultry Diseases. Ethnobotanical leaflets , USA. 13

[10]. Kudi, A. C, and Myint, S.H (1999). Antiviral activity of some Nigeria medicinal plant extracts, Journal of Ethnopharmacology 68, Pp 289-294 
[11]. Oboegbulem, S.I \& Chah, K.F (1997) Retrospective Studies of Diseases of goat in Nsuka, Eastern Nigeria. Bulletin of Animal Health and Production in Africa 45: 235-240

[12]. Odebiyi, O.O \& Sofowora A, (1978) Phytochemical Screening of Nigeria medicinal plants. Part 1. LJ Mat, prod. 41:234-246

[13]. Olanipekun, M.K. (2010) Studies on Ethnoveterinary Botanicals and some aspect of conservation in Ekiti-State. Unpublishd Ph.D Thesis, EKSU Ado-Ekiti.

[14]. Omotoyinbo, M.A \& Kayode, J. (2008) Checklist and conservation status of chewing sticks plants species in Ekiti State, Nigeria Pp. 27-33. In. Research for Development in Forestry, Forest product and Natural Resources Management. Onyekwelu, J.C; Adekunle, V.A.J and Oke, D.O.(Eds.). Proceeding of the conference of forest and forest products Society. Federal University of Technology, Akure, Nigeria. $16^{\text {th }}-18^{\text {th }}$ April, 2008.

[15]. Sondermann, L; Nafere, J. and Leidi,K.A (1993) Baseline support on poultry of the Enukweni Area in Malawi. malawi-German Basi Animal Health Services Project. Mzuzu, Malawi 